\title{
Evidence of traffic-generated air pollution in Havana
}

\author{
Jessie MADRAZO ${ }^{1 *}$, Alain CLAPPIER ${ }^{2}$, Osvaldo CUESTA $^{3}$, Luis C. BELALCÁZAR ${ }^{4}$, Yosdany GONZÁLEZ ${ }^{3}$, \\ Javier BOLUFE' ${ }^{3}$, Carlos $\mathrm{SOSA}^{3}$, Ernesto CARRILLO ${ }^{3}$, Ricardo $\mathrm{MANSO}^{3}$, Janet CANCIANO ${ }^{3}$ \\ and François GOLAY ${ }^{1}$
}

${ }^{1}$ Swiss Federal Institute of Technology of Lausanne, EPFL ENAC IIE LASIG, GCD2 416 (Bâtiment GC) Station 18 CH-1015 Lausanne, Switzerland.

${ }^{2}$ Université de Strasbourg, Laboratoire Image Ville Environnement, 3 rue de l'Argonne, 67000 Strasbourg, France.

${ }^{3}$ Instituto Nacional de Meteorología de Cuba (INSMET), Apartado 17032, Código Postal 11700, Habana 17, Cuba.

${ }^{4}$ Universidad Nacional de Colombia (UNAL), Cra 45 núm. 26-85, Bogotá, Colombia.

*Corresponding author; e-mail: jessie.madrazo@epfl.ch

Received: May 23, 2017; accepted: October 16, 2018

\begin{abstract}
RESUMEN
En La Habana, el sector del transporte es considerado una de las principales fuentes de contaminación atmosférica. Esto se fundamenta en la presencia de una flota de vehículos obsoleta (la mayoría de los modelos son estadounidenses o rusos de las décadas de 1950 o 1980, respectivamente) con deficiente estado técnico. Los estudios existentes se basan en mediciones con captadores pasivos a monitoreo ininterrumpido de $24 \mathrm{~h}$, las cuales pueden no ser representativas de condiciones en las que las concentraciones de contaminantes (partículas o gases) fluctúan o no son homogéneas, tal como es el caso de la contaminación relacionada con el transporte. En este artículo se explora la contaminación generada por el transporte mediante el análisis de correlaciones entre los flujos de tráfico, las concentraciones de contaminantes $\left(\mathrm{PM}_{10}, \mathrm{SO}_{2}, \mathrm{NO}_{2}\right)$ y los parámetros meteorológicos a una menor resolución temporal. Para ello se analizaron las relaciones estadísticas entre todas las variables. Los resultados revelan que el tráfico vehicular influye en las concentraciones de $\mathrm{PM}_{10}, \mathrm{SO}_{2}$ y NO $\mathrm{N}_{2}$, principalmente ante vientos de baja velocidad perpendiculares al eje de la calle. Además del tráfico, los vientos del noreste y sureste arrastran contaminantes de otras fuentes. Estos resultados dependen de las condiciones específicas de la temporada de verano en el área de medición. De obtenerse un conjunto de datos más extensos, un análisis más completo podría llevarse a cabo.
\end{abstract}

\begin{abstract}
In Havana, transport is blamed as a likely source of pollution issues, which is usually supported on arguments referring to a vehicle fleet mainly made of old cars (i.e., most models are American from the 1950s or Russian from the 1980s) with poor technical conditions. Most of the existing studies are based on measurements from passive samplers collected for $24 \mathrm{~h}$, which may not be representative of conditions where pollutant concentrations (particles or gases) fluctuate or are not homogeneous, such as transport-related pollution. The goal of this paper is to explore the transport-generated pollution by examining short-time correlations between traffic flows, pollutant concentrations and meteorological parameters. To do that, statistical relationships among all variables were analyzed, which revealed that $\mathrm{PM}_{10}, \mathrm{NO}_{2}$ and $\mathrm{SO}_{2}$ concentration levels are influenced by vehicular traffic, mainly with low-speed winds blowing perpendicular to the street axis. Furthermore, southeast and northeast winds force drag pollution from sources other than traffic. These conclusions depend on the specific conditions of the summer season at the measurement area. A more complete analysis could be conducted when more data becomes available for each season.
\end{abstract}

Keywords: Air pollution, roadside measurements, traffic source. 


\section{Introduction}

Nowadays, most of the world's population lives in urban areas. According to a United Nations report (UN, 2015), 54\% of the current world's population lives in cities and this proportion is expected to increase to $66 \%$ by 2050 . Unfortunately, the high concentration of human activities (i.e., heating, transport, nutrition, hygiene, health, and other needs) in urban areas involves emissions from the consumption of fossil fuel energy sources; therefore, large amounts of pollutants are released daily into the urban atmosphere. The impacts of this phenomenon on human health are well known; air pollution triggers stroke, cardiovascular and respiratory diseases, which are featured among the top 10 killers in the world (WHO, 2017).

Latin American cities have also experienced important deterioriation in air quality (Bell et al., 2011; Hanif, 2017; Román Collado and Morales Carrión, 2018). According to Gouveia and Leite (2018), Mexico City, Santiago de Chile, Sao Paulo, and Rio de Janeiro host nearly 43 million people and have a large child population exposed to levels of air pollution well above those recommended by the World Health Organization (WHO) guidelines. Statistical evaluations showed significant impacts of air pollution on respiratory mortality in children (Gouveia and Leite, 2018), and health risks markedly higher near sources of pollution (Brugge et al., 2013). The pollution stemming from transport has been significant and growing (Faiz et al., 1995).

In Havana, epidemiologic studies pointed out associations of health hazards proportional to ambient $\mathrm{PM}_{2.5}, \mathrm{PM}_{10}, \mathrm{NO}_{2}$ and $\mathrm{SO}_{2}$. Molina Esquivel et al. (1996) found increased risk of lung cancer by predominant residence $(\geq 40 \mathrm{yrs})$ in $\mathrm{SO}_{2}$ and $\mathrm{PM}_{10}$ high polluted areas. Molina Esquivel et al. (2011) reported high $\mathrm{PM}_{10}$ concentration associated with morbidity and mortality rates. Daily mean black smoke concentration increments of $20 \mu \mathrm{g} \mathrm{m}^{-3}$ and $\mathrm{SO}_{2}$ were associated with increments of $2.4 \%$ on child acute respiratory infections in the period from October 1996 to March 1998 (Romero Placeres et al., 2004); and correlations between daily mean concentrations, meteorological parameters (i.e., temperature, wind speed, and direction) and respiratory morbidity indicators showed respiratory diseases highly influenced by $\mathrm{PM}_{10}$ values reaching WHO risk limits on the period from October 1996 to September 1997 (Molina Esquivel et al. 2001a, b). Most of these studies recurrently point to PM as the pollutant with major impact on the health of Havana citizens and attribute the high levels of $\mathrm{PM}_{2.5}$ and $\mathrm{PM}_{10}$ pollution to the poor technical condition of vehicles (Molina Esquivel et al. 2015, 2017).

Designating transport as a likely source of Havana air pollution issues is usually supported by arguments referring to a mainly old vehicle fleet (most models are American from the 1950s or Russian from the 1980s) with low fuel efficiency and high emission systems (cf. Ding et al., 2004; Romero Placeres et al., 2004; Molina Esquivel et al., 2001a, b, 2011, 2017; Martínez Varona et al., 2011). Only a few studies have relied on the use of tools to report evidence (cf. Molina Esquivel et al., 2015; Martínez Varona et al., 2018). Their measurements have been obtained from 24-h data collected with passive samplers, then followed by chemical analysis in the laboratory. For PM, low volume gravimetric analytical methods were used, while $\mathrm{SO}_{2}$ and $\mathrm{NO}_{2}$ gases were measured by diffusive devices (spectrophotometric, absorption method) with a minimum 24-h sampling exposition. These setting techniques may not reproduce conditions where pollutant concentrations (particles or gases) fluctuate or are inhomogeneous, such as in transport-related pollution. So far, evidencing traffic-related air pollution has been a challenge, since passive monitoring can only detect the concentration of ambient air pollution caused by various factors as a whole (Cuesta Santos et al. 2012; Pan et al. 2016).

In this work, we explore traffic-generated pollution in Havana by analyzing shorter-time correlations between traffic flows, pollutant concentrations and meteorological parameters. We consider that this approach avoids the difficulty of discriminating between traffic-related air pollution and ambient air pollution. A measurement campaign was carried out on an important street of Havana where traffic volumes, some traffic-related pollutants (i.e., $\mathrm{PM}_{10}$, $\mathrm{SO}_{2}$, and $\mathrm{NO}_{2}$ ) and meteorological parameters were rated with proper temporal resolution. Then, statistical relationships among all variables were analyzed, aiming to show how strong pollutant measurements are influenced by traffic flows during specific meteorological episodes. 


\section{Measurement campaign}

The measurement campaign took place on Simón Bolívar Street (Fig. 1) close to the center of Havana, during 10 days in the summer of 2015 . This street is an urban corridor built prior to the beginning of 20th century where important daily commuting movements take place; it is about $12 \mathrm{~m}$ wide with an east-west direction. According to the average height of the surrounding buildings (about $15 \mathrm{~m}$ ) it is classified as an urban canyon (height/width ratio of 1.25).

The diurnal traffic flow along the street was continuously recorded with a GoPro video camera placed on the north side of the street, about $200 \mathrm{~m}$ away from the nearest traffic light intersection, at a proper elevation to capture all traffic lanes (see Fig. 1 for more details). Traffic volumes were manually counted after the measuring campaign from the video recordings and aggregated into clearly identifiable categories, i.e., motorcycles, modern cars, median-age cars (of Russian origin), old-age cars (of American origin), high-capacity buses, low-capacity buses, and trucks.

Devices for measuring $\mathrm{PM}_{10}, \mathrm{NO}_{2}$, and $\mathrm{SO}_{2}$ air pollution were installed $1.5 \mathrm{~m}$ above the ground. A Thermo-Scientific ADR 1500 was used for PM;

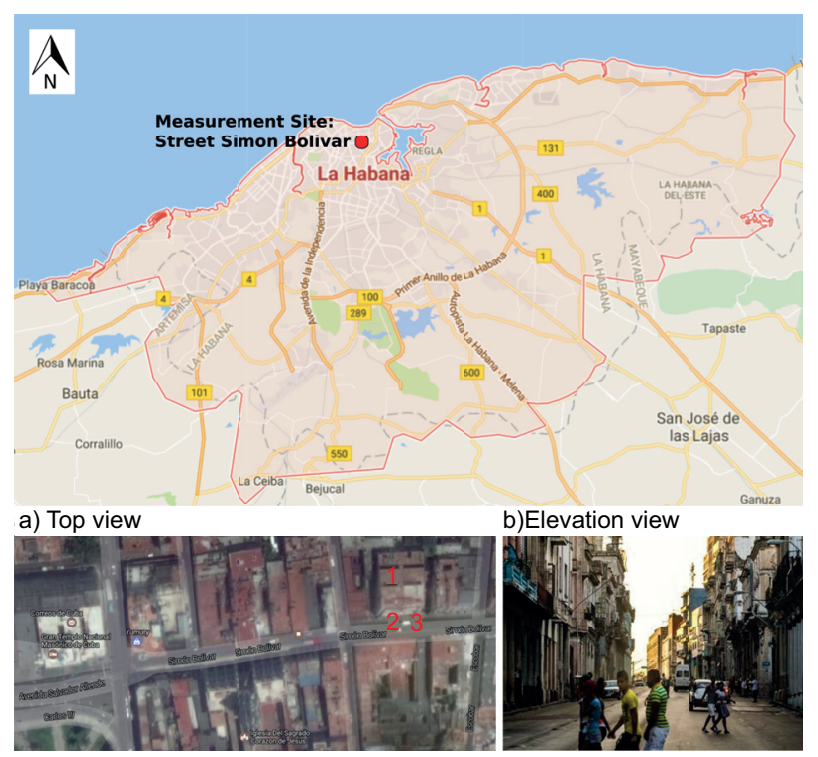

Fig. 1. Location of the masurement site at Simón Bolívar Street in Havana City (red point). Adapted from Google earth map: (a) Street top view with the meteorological station (1) traffic video recording (2), and pollutant measurement devices (3); (b) street elevation view. it incorporates light scattering photometry, optical sensing and electronic processing techniques to measure precisely a selected size of suspended particles down to $1 \mu \mathrm{g} \mathrm{m}^{-3}$. It was set to provide real-time $\mathrm{PM}_{10}$ concentrations every minute from 07:00 to 19:00 LT. The concentrations of pollutant gases were captured from chemical adsorption (i.e., a chemical reaction between the given gas and an adsorbing substance). CT-112 and CT-212 bearers (Volberg 1982) of tetrachloromercurate and potassium iodide were used as sorbent tubes sampling for a 1-h step at accurately known flow rates of 1.0 and $0.25 \mathrm{~L} / \mathrm{min}$. They were measured by visible spectrophotometric techniques at 540 and $575 \mathrm{~nm}$ wavelengths, respectively. The mass of gases in each tube was determined from calibration curves; then concentration levels of $\mathrm{SO}_{2}$ and $\mathrm{NO}_{2}$ were calculated by applying the corresponding conversion factors, i.e. 2.830 for $\mathrm{SO}_{2}$ and 17.294 for $\mathrm{NO}_{2}$. For both pollutant gases, the limits of detection and quantitation were 0.1 and $500 \mu \mathrm{g} \mathrm{m}^{-3}$ respectively. All pollutant measurements were suspended during rainfall episodes to discard events of substantial pollutant concentration decline due to washing out of particles and absorption of pollutants.

A meteorological station and radio wave transmission housing were placed on the roof of the nearest building. This edifice is the highest point $(\sim 20 \mathrm{~m}$ high) within a 1-km radius. The registered meteorological parameters were temperature, solar radiation, atmospheric pressure, humidity, wind speed, and direction. All data were automatically stored in a computer at a 1-min step resolution.

\section{Result and discussion}

\subsection{Traffic flows}

More than 15000 vehicles were counted daily over the campaign period (Fig. 2). The fleet mainly comprises light-duty cars (i.e., modern cars [27.6\%], medium-age cars [16.2\%], and old cars [33.0\%]). Merely $8.9 \%$ of the fleet is comprised by motorcycles and $14.3 \%$ by heavy-duty vehicles including buses and trucks. This composition is rather typical in Havana. Figure 2a shows that light-duty categories (especially old vehicles) are responsible for the highest flow variability. In Figure 2b, hourly fluctuations of traffic flow produce wider but visibly distinguishable peaks; 

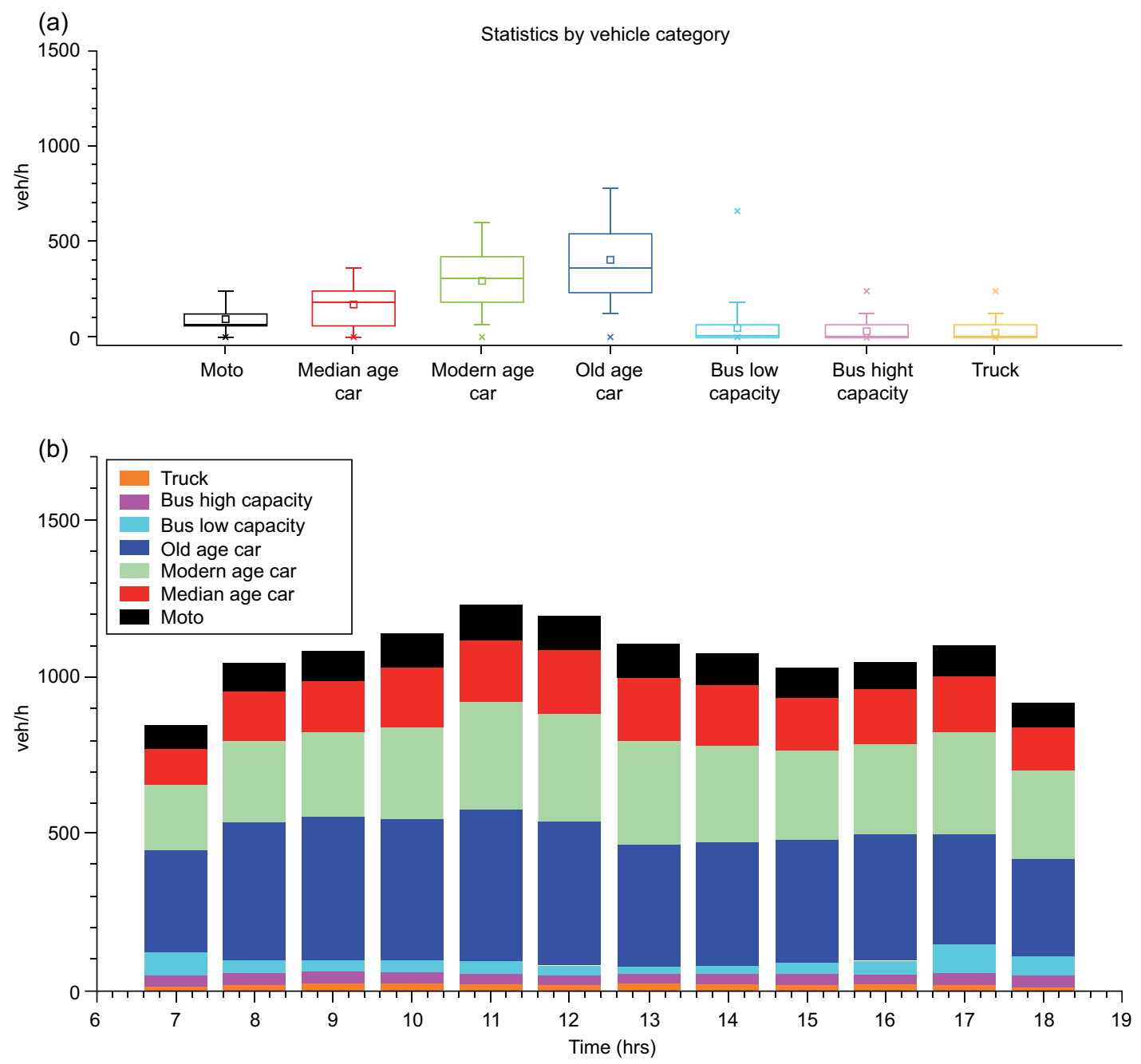

Fig. 2. Traffic data: (a) box plots of vehicle categories, (b) hourly flows.

during the morning, traffic increases until 11:00 LT and then subtly decreases prior to 17:00 LT, when a new peak appears.

\subsection{Concentration levels}

Hourly diurnal $\mathrm{PM}_{10}, \mathrm{NO}_{2}$, and $\mathrm{SO}_{2}$ measurements are shown in Figure 3. The $\mathrm{PM}_{10}$ plot was obtained by averaging the 1 -min step measurements over $1 \mathrm{~h}$ from all data gathered during the campaign. $\mathrm{PM}_{10}$ diurnal average fluctuates close to the mean value ranging from 88 to $115 \mu \mathrm{g} \mathrm{m}^{-3}$. $\mathrm{NO}_{2}$ and $\mathrm{SO}_{2}$ ranged from 72 to 138 and 14 to $40 \mu \mathrm{g} \mathrm{m}^{-3}$, respectively. These values are higher than the means reported on previous studies for $\mathrm{PM}_{10}\left(30-61 \mu \mathrm{g} \mathrm{m}^{-3}\right), \mathrm{NO}_{2}\left(8-20 \mu \mathrm{g} \mathrm{m}^{-3}\right)$ and $\mathrm{SO}_{2}\left(1.5-24 \mu \mathrm{g} \mathrm{m}^{-3}\right.$ ) (Molina Esquivel et al., 2001a;
Martínez Varona et al., 2013; Cruz Rodríguez and Valdivia Pérez, 2017). These differences could be traced to the use of measurement settings (e.g., sampling height and duration) that differed from the referenced studies.

In Figure 3, the $\mathrm{PM}_{10}$ fluctuations do not seem to follow completely the increase of the middle morning traffic (Fig. 2b); nevertheless, after 11:00 LT a better correspondence with the traffic profile is observed. $\mathrm{NO}_{2}$ exhibits the highest values on morning hours; before 9:00 LT, the pollutant profile seems to be inversely correlated with traffic flows. However, after noontime, $\mathrm{NO}_{2}$ levels fall further and then rise around 15:00 LT in a modest accordance with traffic trends. For $\mathrm{SO}_{2}$, the almost constant temporal profile 

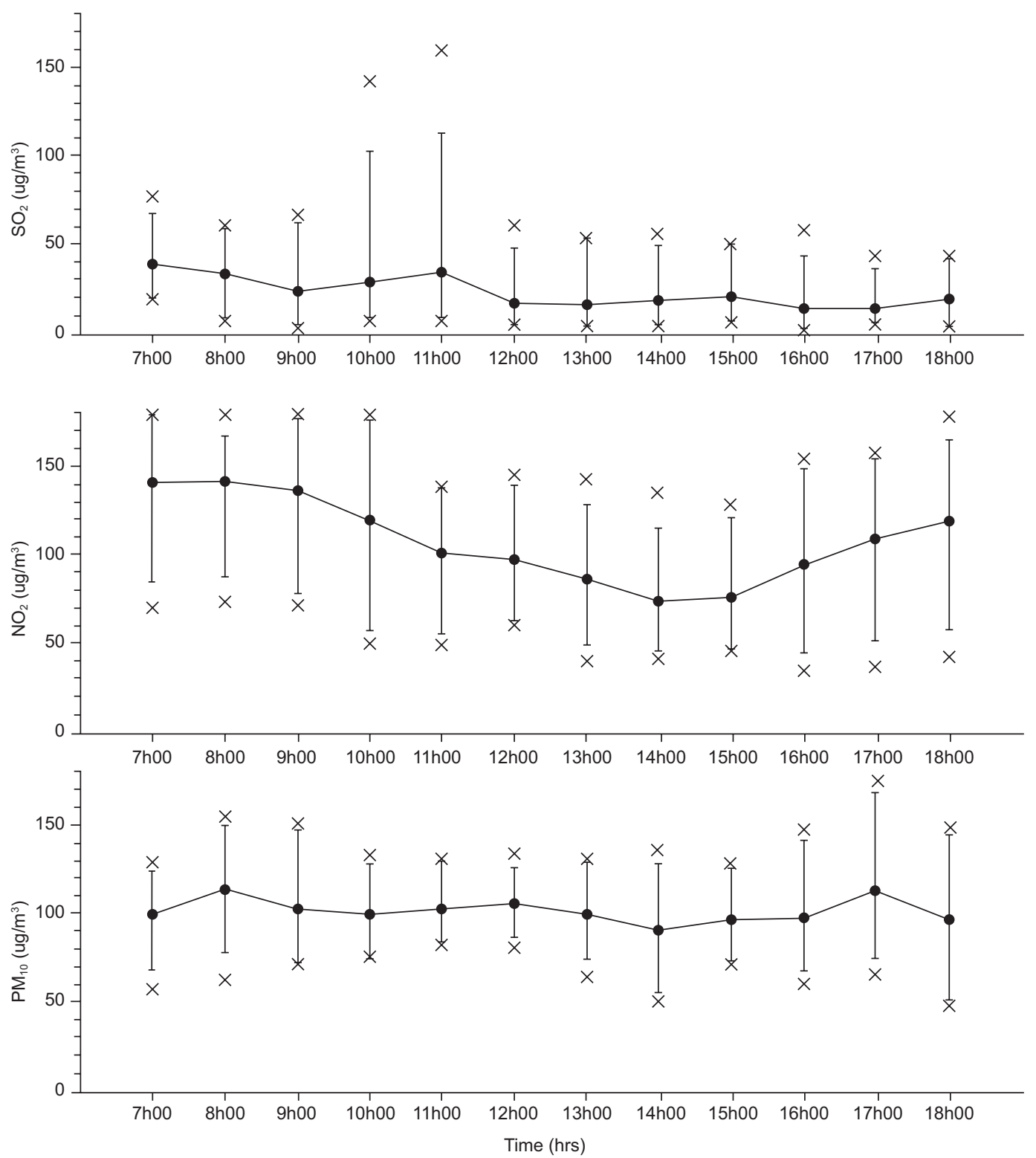

Fig. 3. Average diurnal variations of $\mathrm{PM}_{10}, \mathrm{NO}_{2}$, and $\mathrm{SO}_{2}$.

(with exception of some observations that went beyond limits) suggests that contributions from stable sources are more important than the vehicle ones.

Regarding $\mathrm{SO}_{2}$ variations, no inferences could be made on whether or not they are interrelated with local traffic flows. Indeed, these pollution trends analyses are indicative of concentration-response at street level from all emission sources; single-handedly, they do not provide conclusive insights about the traffic-generated pollution behavior.

\subsection{Meteorological parameters}

Meteorological data analysis focused on wind speed and direction as high-influencing parameters of pollutant dispersion. Figure 4 shows wind roses of $3-\mathrm{h}$ intervals (i.e., 7:00-10:00, 10:00-13:00, 13:00-16:00, and 16:00-19:00 LT). Two different regimes can be observed: during the first interval, winds come from the south-southeast at a relatively low speed while on the other periods wind mainly comes from the north-northeast at higher speeds. 

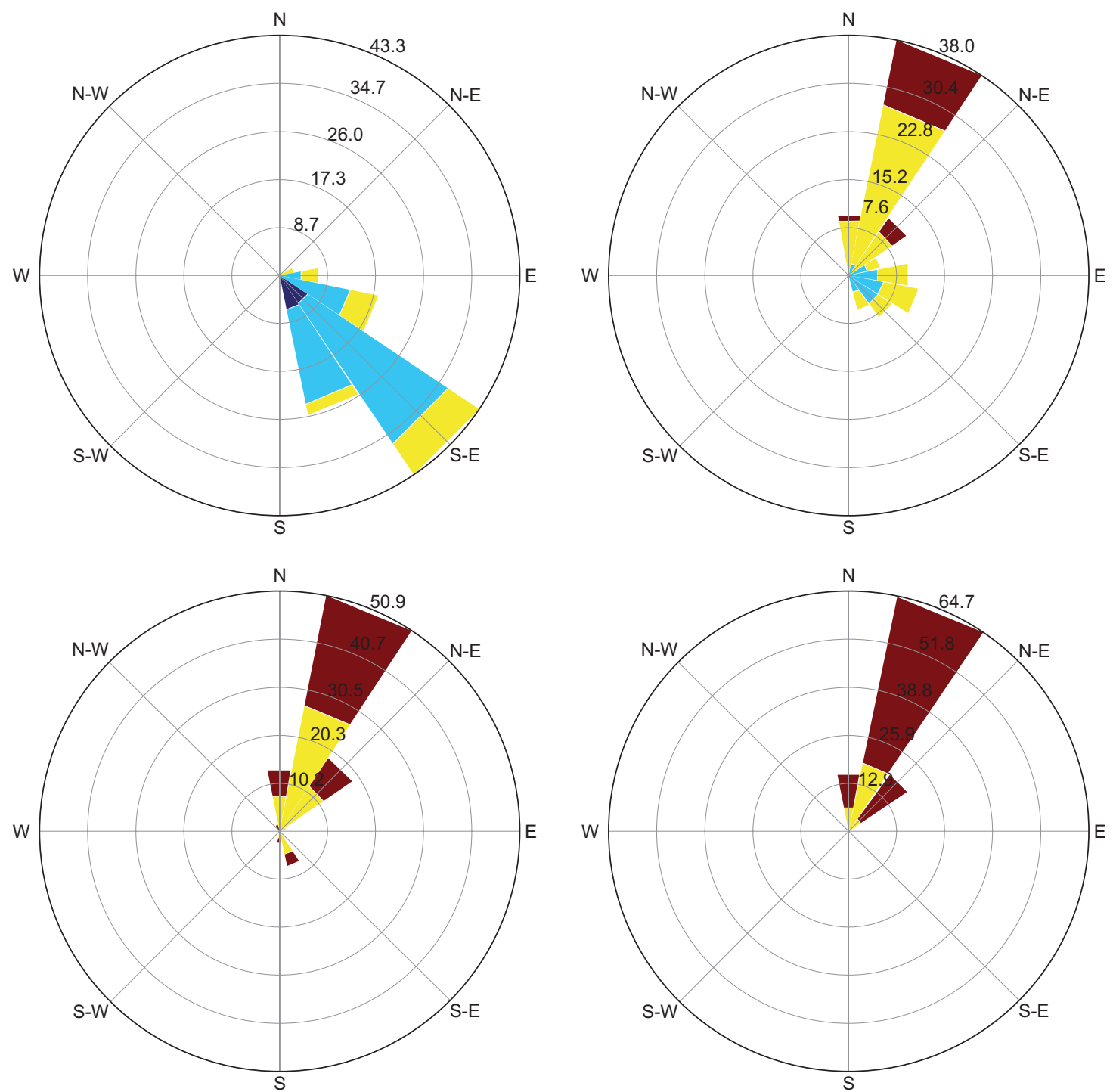

$0-2 \mathrm{~m} / \mathrm{s}$

$2-4 \mathrm{~m} / \mathrm{s}$

Fig. 4. Wind roses of average diurnal variation of wind forces. 7:00-10:00 LT (top-left), 10:00-13:00 LT (top-right), 16:00-19:00 LT (down-left), and 13:00-16:00 LT (down-right).

These observations agree with the theory of sealand breezes suggested by Simpson (1996). A delayed offshore breeze can be observed on the first wind rose; on the previous night, the land loses heat quickly after the sun sets down and the air above also cools. Water has much higher thermal inertia (i.e., very little day/ night temperature change). The relatively warm air over the sea causes low pressure. Over the land, high surface pressure will develop because of colder air; to compensate, the wind blows from higher pressure over the land to lower pressure over the sea causing a land breeze (Ding et al., 2004). During the middle morning, the wind starts the reverse phenomenon on the so-called sea breeze; the sun heats up both the sea surface and land; however, water heats up much more slowly than land, so the air above land will be warmer compared to the air over the sea. This causes a wind blowing from the sea inland. 
It is believed that land-see breezes generate specific pollutant motion regimes inside the street canyon and therefore influence traffic contributions: according to Berkowicz et al. (1997), Berkowicz (1998), and Kastner-Klein et al. (2003), the wind flows at street level and the pollutant recirculation features depend on roof-level wind flows. The street-level wind inside the recirculation zone forms an angle with the street axis, which is equal to that of wind direction at roof level with respect to the street axis but with transverse component (i.e., as a mirror reflection). Outside the recirculation zone, the wind direction is the same that at roof level. Also, the variability of the wind directions across the measurement site may explain the existence of different air pollution behaviors.

\subsection{Statistical relationships between traffic flow, pollutant concentration, and wind forces}

As aforementioned, the wind flow regimes are expected to influence pollutant concentration levels, since they change the features of pollutant motion and limit the scope of surrounding pollution sources.

In Figure 5, bivariate polar plots allow for understanding the sources of pollution according to prevalent wind flow profiles (i.e., land [7:00-10:00 LT] and sea [13:00-19:00 LT] breezes). During the morning, $\mathrm{PM}_{10}$ tends to be highest $\left(140 \mu \mathrm{g} \mathrm{m}^{-3}\right)$ under low and perpendicular (with respect to the street axis) wind conditions, pointing to ground level source contributions such as traffic. $\mathrm{NO}_{2}$ does not vary with the variation of wind speeds, suggesting also traffic contributions. However, it tends to increase (from 100 to $200 \mu \mathrm{g} \mathrm{m}^{-3}$ ) as wind direction changes from south to east; at this point, contributions from non-traffic sources become more significant with high-speed wind. $\mathrm{SO}_{2}$ decrease (from 45 to $20 \mu \mathrm{g} \mathrm{m}^{-3}$ ) as wind directions change from south to east and remain almost constant under wind speed fluctuations. This highlights the influence of ground-level sources for wind blowing perpendicularly to the street axis. During the afternoon, pollutants variations were less pronounced compared to the morning. $\mathrm{PM}_{10}$ subtly increases (from 80 to $100 \mu \mathrm{g} \mathrm{m}^{-3}$ ) as wind direction shifts from southeast to northeast. $\mathrm{SO}_{2}$ tends to peak under high wind speed conditions at northeast, pointing to the existence of important sources other than traffic. $\mathrm{NO}_{2}$ is less influenced by wind conditions.

To better emphasize the strength of traffic contributions, statically significant correlations between pollutants and flows of specific vehicle categories, including several alternative aggregation schemes, were set. Best results were found by grouping vehicles of similar emission profiles (i.e., buses and trucks were aggregated on the "Heavy" category, medium and old-age light-duty vehicles were aggregated on the "MedOld" category, and motorcycles and modern light-duty vehicles remained as single categories; see Table I).

Morning rises in $\mathrm{PM}_{10}$ are coupled with rises in traffic, indicating that $\mathrm{PM}_{10}$ concentration levels were likely induced by vehicle emissions. The

Table I. Significant correlations ( $\mathrm{p}$-value $<0.05$ )* between pollutants and vehicular flow.

\begin{tabular}{lccccccc}
\hline & \multicolumn{3}{c}{ Morning } & & \multicolumn{3}{c}{ Afternoon } \\
& \multicolumn{3}{c}{$07: 00-10: 00$} & & \multicolumn{3}{c}{$13: 00-18: 00$} \\
\cline { 2 - 5 } \cline { 6 - 8 } & $\mathrm{PM}_{10}$ & $\mathrm{NO}_{2}$ & $\mathrm{SO}_{2}$ & & $\mathrm{PM}_{10}$ & $\mathrm{NO}_{2}$ & $\mathrm{SO}_{2}$ \\
\hline Motorcycles & $\mathbf{0 . 6 8}$ & - & - & & 0.42 & 0.49 & 0.36 \\
& $7 e-04$ & & & & $6 e-03$ & $1 e-02$ & $2 e-02$ \\
Modern vehicles & $\mathbf{0 . 7 4}$ & - & 0.45 & & 0.41 & 0.47 & 0.39 \\
& $3 e-05$ & & $4 e-02$ & & $8 e-03$ & $2 e-02$ & $1 e-02$ \\
Med-old vehicles & $\mathbf{0 . 7 8}$ & - & - & & - & - & $\mathbf{0 . 5 4}$ \\
& $1 e-04$ & & & & & & $4 e-02$ \\
Heavy & $\mathbf{0 . 6 3}$ & - & $\mathbf{0 . 5 3}$ & & $\mathbf{0 . 6 5}$ & $\mathbf{0 . 6 3}$ & - \\
& $2 e-03$ & & $1 e-02$ & & $9 e-04$ & $7 e-04$ & \\
Total vehicles & $\mathbf{0 . 8 3}$ & - & - & & $\mathbf{0 . 5 0}$ & $\mathbf{0 . 5 3}$ & 0.39 \\
& $7 e-06$ & & & & $1 e-02$ & $3 e-02$ & $1 e-02$ \\
\hline
\end{tabular}

*This indicates that there is a $5 \%$ risk of concluding that a correlation exists, i.e., changes in vehicle categories are related to changes in pollutant concentration levels. 

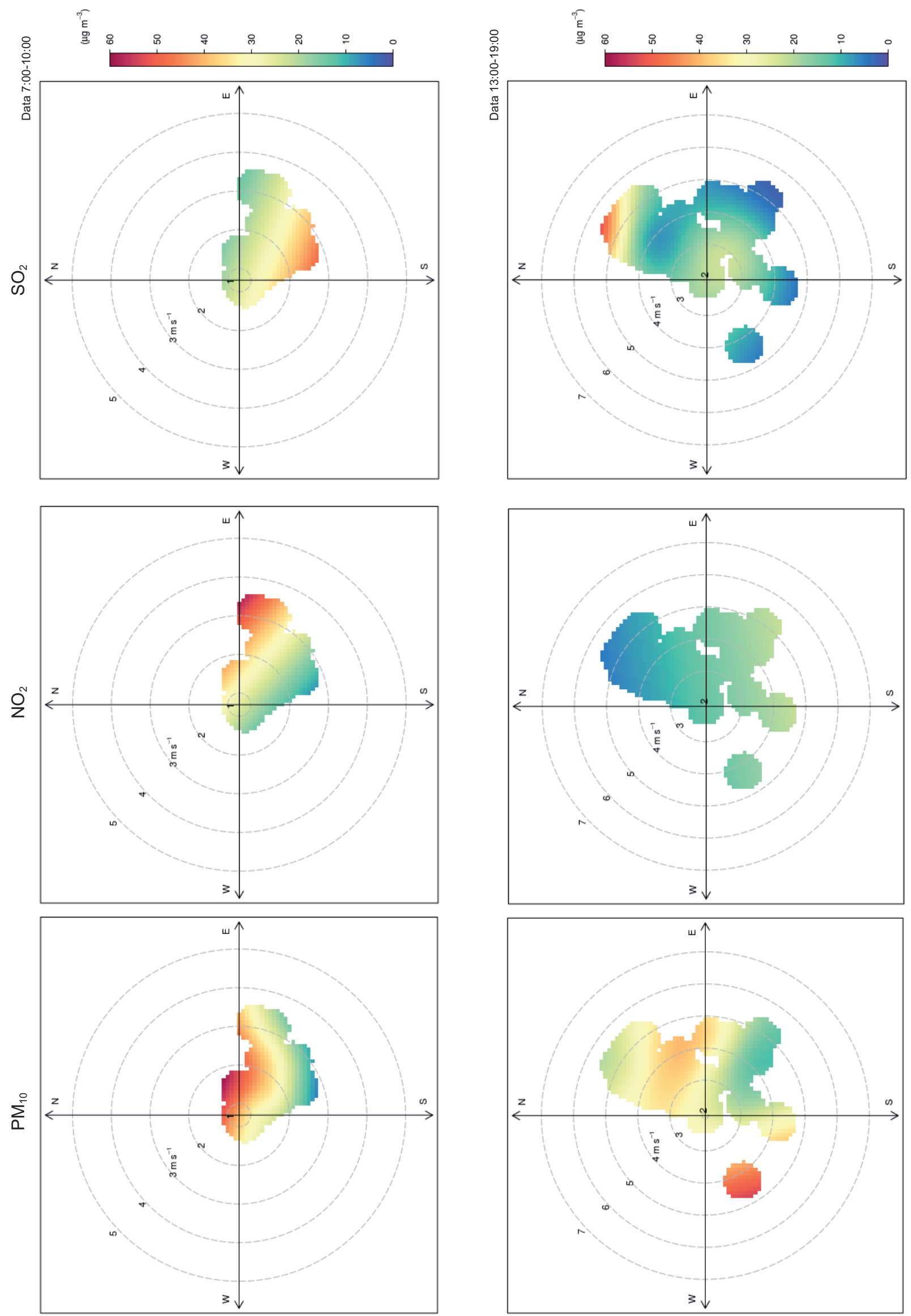

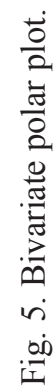


correlation between $\mathrm{SO}_{2}$ and vehicle emissions is moderate, mostly influenced by heavy vehicles traffic. During afternoons, all pollutants correlate acceptably. $\mathrm{PM}_{10}$ and $\mathrm{NO}_{2}$ are highly influenced by heavy vehicles, while $\mathrm{SO}_{2}$ is coupled with changes in old and medium-age vehicles. The statistically significant relationships for variables in Table I indicate that the three pollutants do account for traffic contributions, which increase under specific meteorological conditions.

\section{Conclusion}

Aiming to evidence traffic-generated air pollution in Havana, statistical tools were applied to a set of pollutant, traffic and meteorological measurements (1-h samples). Statistically significant relationships between hourly traffic and pollutant measurements indicated that $\mathrm{PM}_{10}, \mathrm{NO}_{2}$, and $\mathrm{SO}_{2}$ account for traffic contributions. Morning $\mathrm{PM}_{10}$ pollution is mostly influenced by traffic. $\mathrm{PM}_{10}, \mathrm{NO}_{2}$ and $\mathrm{SO}_{2}$ traffic-generated pollution increases with low-speed winds which blow perpendicular to the street axis. In addition to traffic, emissions from other sources seem to be dragged by winds from the southeast/ northeast (morning/afternoon) inducing variations, mainly in the pollution levels of $\mathrm{NO}_{2}$ and $\mathrm{SO}_{2}$. These conclusions are dependent on specific wind conditions of the Cuban summer season at the measurement area. A more complete analysis could be conducted when more data becomes available for other seasons.

\section{Acknowledgments}

The authors thank the Swiss National Science Foundation (SNF) for the funding provided to this project and the Urbamo Cuba Association $(\mathrm{CH})$ for providing all the equipment used in the Havana campaign.

\section{References}

Bell M.L., Cifuentes L.A., Davis D.L., Cushing E., Gusman A. and Gouveia N., 2011. Environmental health indicators and a case study of air pollution in Latin American cities. Environ. Res. 111, 57-66.

DOI: 10.1016/j.envres.2010.10.005
Berkowicz R., Hertel O., Larsen S.E., Sørensen N.N. and Nielsen M., 1997. Modelling traffic pollution in streets. National Environmental Research Institute, Ministry of Environment and Energy, Roskilde, Denmark, $55 \mathrm{pp}$.

Berkowicz R., 1998. Street scale models. In: Environmental pollution (Fenger J., Hertel O. and Palmgren F., Eds.). Springer, Dordrecht, 223-251. DOI: 10.1007/978-94-015-9080-8 12

Brugge D., Lane K., Padró-Martínez L.T., Stewart A., Hoesterey K., Weiss D., Wang D.D., Levy J.I., Patton A.P., Zamore W. and Mwamburi M., 2013. Highway proximity associated with cardiovascular disease risk: The influence of individual-level confounders and exposure misclassification. Environ. Health 12, 84. DOI: 10.1186/1476-069X-12-84

Cruz Rodríguez L. and Valdivia Pérez J.A., 2017. Cuantificación de la concentración de $\mathrm{Zn}, \mathrm{Cu}, \mathrm{Pb}$ y $\mathrm{Cd}$ en partículas menores de $10 \mu \mathrm{m}$ procedentes del aerosol atmosférico: clasificación de las fuentes contaminantes en la zona de estudio. Revista Killkana Técnica 1, 17-24.

Cuesta Santos O., Fonseca M., Manrique R. and Carrillo E., 2012. Evaluación de la calidad del aire en ciudades de Cuba. Convención Internacional Trópico 2012, La Habana, Cuba, Mayo.

Ding A., Wang T., Zhao M., Wang T. and Li Z., 2004. Simulation of sea-land breezes and a discussion of their implications on the transport of air pollution during a multi-day ozone episode in the Pearl River Delta of China. Atmos. Environ. 38, 6737-6750.

DOI: 10.1016/j.atmosenv.2004.09.017

Faiz A., Gautama S. and Burkib E., 1995. Air pollution from motor vehicles: Issues and options for Latin American countries. Sci. Total. Environ. 169, 303-310. DOI: $10.1016 / 0048-9697(95) 04662-K$

Gouveia N. and Leite W., 2018. Effects of air pollution on infant and children respiratory mortality in four large Latin-American cities. Environ. Pollut. 232, 385-391. DOI: 10.1016/j.envpol.2017.08.125

Hanif I., 2017. Economics-energy-environment nexus in Latin America and the Caribbean. Energy 141, 170-178.

DOI:10.1016/j.energy.2017.09.054

Kastner-Klein P., Fedorovich E., Ketzel M., Berkowicz R. and Britter R, 2003. The modelling of turbulence from traffic in urban dispersion models - Part II: Evaluation against laboratory and full-scale concentration 
measurements in street canyons. Environ. Fluid. Mech. $3,145-172$.

DOI: 10.1023/A:1022049224166

Martínez Varona M., Maldonado G., Molina Esquivel E. and Fernández Arocha A., 2011. Concentraciones diarias de contaminantes del aire en La Habana (Cuba). Hig. Sanid. Ambient. 792, 786-792.

Martínez Varona M., Molina Esquivel E., Maldonado Cantillo G., Guzmán Vila M. and Alonso García D., 2013. Comportamiento de partículas menores de 10 micras mediante dos equipos de monitoreo. Hig. Sanid. Ambient. 13, 1060-1065.

Martínez Varona M., Vila Guzmán M., Pérez Cabrera A. and Férnandez Arocha A., 2018. Presencia de metales pesados en material particulado en aire. Estación de monitoreo INHEM, Centro Habana. Biblioteca Ecosolar, 1-10.

Molina Esquivel E., Barceló Pérez C., Bonito Lara L.A. and del Puerto Quintana C., 1996. Factores de riesgo de cáncer pulmonar en Ciudad de La Habana. Revista Cubana Hig. Epidemiol. 34, 1-8.

Molina Esquivel E., Browns Colás L.A., Prieto Díaz V., Cuellar L. and Rodríguez D., 2001a. Contaminación atmosférica y prevalencia de asma en Centro Habana. Revista Cubana Hig. Epidemiol. 39, 5-15.

Molina Esquivel E., Browns Colás L.A., Prieto Díaz V., Bonet Gordea M. and Cuéllar Luna L., 2001b. Crisis de asma y enfermedades respiratorias agudas. Contaminantes atmosféricos y variables meteorológicas en Centro Habana. Revista Cubana Med. Gen. Integr. 17, 10-20.

Molina Esquivel E., Zayas G.P., Martínez Varona M., Hernández I.P., Gala R.G., Ugalde F.A. and Maldonado Cantillo G., 2011. Comportamiento de las fracciones fina y gruesa de $\mathrm{PM}_{10}$ en la estación de monitoreo de calidad del aire en Centro Habana. Campaña 20062007. Hig. Sanid. Ambient. 11, 820-826.

Molina Esquivel E., Martínez Varona M., Turtós Carbonell L.M., Meneses Ruiz E., García Dos S., Cuesta Zedeño L.F. and Pire Rivas S., 2015. Carbono elemental y orgánico en $\mathrm{PM}_{2.5}$ y $\mathrm{PM}_{10}$ de zonas urbanas de La Habana (Cuba). Hig. Sanid. Ambient. 15, 1343-1349.
Molina Esquivel E., Meneses Ruiz E., Turtós Carbonell L.M., Guzmán Vila M., Alonso García D., Martínez Varona M., González C. and Pérez G., 2017.

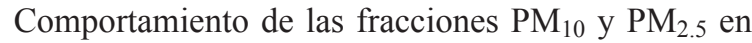
tres zonas de La Habana (2012). Hig. Sanid. Ambient. 17, 1553-1564.

Pan L., Yao E. and Yang Y., 2016. Impact analysis of traffic-related air pollution based on real-time traffic and basic meteorological information. J. Environ. Manage. 183, 510-520. DOI: 10.1016/j.jenvman.2016.09.010

Román Collado R. and Morales Carrión A.V., 2018. Towards a sustainable growth in Latin America: A multiregional spatial decomposition analysis of the driving forces behind $\mathrm{CO}_{2}$ emissions changes. Energ. Policy. 115, 273-280. DOI: 10.1016/j.enpol.2018.01.019

Romero Placeres M., Más Bermejo P., Lacasaña Navarro M., Rojo Solís M., Téllez M., Aguilar Valdés J. and Romieu I., 2004. Contaminación atmosférica, asma bronquial e infecciones respiratorias agudas en menores de edad de La Habana. Salud Pública Mex. 46, 222-233.

Simpson J.E., 1996. Diurnal changes in sea-breeze direction. J. Appl. Meteorol. 35, 1166-1169.

DOI: 10.1175/1520-0450(1996)035<1166:DCISB$\mathrm{D}>2.0 . \mathrm{CO} ; 2$

UN, 2015. World urbanization prospects. The 2014 revision. United Nations, Department of Economic and Social Affairs, Population Division, New York, 493 pp. Available at: https://esa.un.org/unpd/wup/publications/ files/wup2014-report.pdf.

Volberg B., 1982. Instrucciones metodológicas provisionales para el análisis químico del aire atmosférico por los tubos de absorción. Comité Estatal de Hidrometeorología. Leningrado, URSS, $34 \mathrm{pp}$.

WHO, 2017. Air pollution. World Health Organization, Geneva. Available at: https://www.who.int/airpollution/en/. 